\title{
KONDISI GEOMORFOLOGI DAN KARAKTERISTIK SEDIMEN DASAR LAUT DI WILAYAH PERAIRAN SEBAGIN UNTUK EVALUASI TAPAK PLTN DI BANGKA SELATAN
}

\author{
Yuliastuti, Heni Susiati, dan Yarianto Sugeng Budi Susilo \\ Pusat Kajian Sistem Energi Nuklir (PKSEN), BATAN \\ Jalan Kuningan Barat, Mampang Prapatan, Jakarta Selatan \\ Telp/ Fax.: (021) 5204243 E-mail: yuliastuti@batan.go.id
}

\begin{tabular}{|c|c|c|}
\hline Diterima & Diterima dalam bentuk revisi & Disetujui \\
\hline 14 Agustus 2015 & 12 Oktober 2015 & 26 Oktober 2015 \\
\hline
\end{tabular}

\begin{abstract}
ABSTRAK
KONDISI GEOMORFOLOGI DAN KARAKTERISTIK SEDIMEN DASAR LAUT DI WILAYAH PESISIR PERAIRAN SEBAGIN UNTUK EVALUASI TAPAK PLTN DI BANGKA SELATAN. Telah dilakukan penelitian mengenai kondisi geomorfologi dan karakteristik sedimen dasar laut di wilayah perairan Sebagin, Bangka Selatan. Informasi geomorfologi dasar laut sangat berguna dalam hal interpretasi struktur-struktur geologi yang berada di dasar laut. Sedangkan informasi karakteristik sedimen dasar laut bermanfaat untuk memberikan gambaran pelapisan batuan dasar laut dalam kaitannya dengan kestabilan tapak PLTN terkait aspek kegempaan dan penentuan posisi water intake. Tujuan penelitian untuk mengevaluasi kondisi geomorfologi dan karakterisasi sedimen dasar laut di perairan Sebagin, Bangka Selatan. Metodologi yang dipakai untuk mengevaluasi kondisi geomorfologi dasar laut adalah Multi Beam Echo Sounder (MBES) dan Single Beam Echo Sounder (SBES), sedangkan untuk karakterisasi sedimen dasar laut dilakukan dengan pengukuran seismik refleksi resolusi tinggi menggunakan sub bottom profiling (SBP) dan uji sampel sedimen di daerah penelitian. Hasil penelitian menunjukkan bahwa daerah penelitian merupakan perairan dangkal dengan kedalaman 1- $59 \mathrm{~m}$. Profil geomorfologi dasar laut daerah penelitian cenderung tidak beraturan dan berdasarkan interpretasi seismik tidak ditemukan adanya patahan. Hasil analisis sedimen dasar laut menunjukkan bahwa, distribusi lumpur mendominasi daerah penelitian.
\end{abstract}

Kata Kunci: geomorfologi, tapak PLTN, sedimen, sub bottom profile.

\begin{abstract}
GEOMORPHOLOGICAL CONDITION AND SEA BOTTOM SEDIMENT CHARACTERISTICS OF SEBAGIN COAST FOR NPP SITE EVALUATION IN SOUTH BANGKA. Study on geomorphological condition and sea bottom sediment in the coastal area of Sebagin, South Bangka Regency, Bangka Belitung Province has been performed. Geomorphological of the seabed was valuable to identify geological structures that exist on the seabed layers. Whereas, sediments seabed characteristics was useful to provide portrait of seabed layer due to the stability of NPP site concerning the seismic aspect and the determination of water intake position. The objective of the study was to evaluate geomorphological condition and sea bed sediment characteristics in the South Bangka sea. Methodology used for evaluating geomorphological of the sea bed were Multi Beam Echo Sounder (MBES) and Single Beam Echo Sounder (SBES), while for sea bottom sediment characteristics, high resolution seismic reflection using SBP together with sediment sample analysis were used. The result of the study showed that the study area was a shallow water sea with a depth range of 1-59 $\mathrm{m}$. Geomorphological profile of the sea bed tend to be irregular and based on the seismic interpretation, there were no fault exists. Result analysis on the sea bottom sediment showed that clay distribution dominated the study area.
\end{abstract}

Keywords: geomorphology, NPP site, sediment, sub bottom profile. 


\section{PENDAHULUAN}

Evaluasi tapak Pembangkit Listrik Tenaga Nuklir (PLTN) menjadi hal yang krusial untuk dilakukan dalam menentukan keberterimaan tapak dan penentuan kriteria basis desain PLTN. Pelaksanaan evaluasi tapak PLTN mengacu pada Peraturan Kepala BAPETEN No. 5 tahun 2007 tentang Ketentuan Keselamatan Evaluasi Tapak Reaktor Nuklir. Salah satu aspek yang dipertimbangkan dalam evaluasi tapak adalah kondisi geomorfologi dan karakteristik sedimen dasar laut yang merupakan bagian dari aspek hidrologi. Informasi geomorfologi dasar laut sangat berguna dalam hal interpretasi struktur-struktur geologi yang berada di dasar laut. Sedangkan informasi karakteristik sedimen dasar laut bermanfaat untuk memberikan gambaran perlapisan batuan dasar laut dalam kaitannya dengan kestabilan tapak PLTN terkait aspek kegempaan dan penentuan posisi water intake.

Evaluasi tapak PLTN telah dilakukan di pesisir di Teluk Menggris, Tanah Merah, kecamatan Muntok, Kabupaten Bangka Barat, pesisir Tanjung Batu Berdaun-Tanjung Berani, desa Sebagin, Kecamatan Simpang Rimba, Bangka Selatan [1,2]. Pemilihan lokasi tapak dilakukan dengan mempertimbangkan beberapa aspek dalam pemilihan lokasi tapak sesuai dengan peraturan yang berlaku.

Bangka Selatan merupakan lokasi yang telah dipilih untuk menjadi lokasi tapak PLTN di samping tapak PLTN yang telah terpilih di daerah Tanah Merah, Muntok, Bangka Barat. Umur batuan yang membentuk pulau Bangka sangat tua, diperkirakan dari masa Jurassic sekitar 200 juta tahun lalu, sehingga sangat stabil dan sesuai untuk dijadikan tapak PLTN ${ }^{[1]}$.

Penelitian ini bertujuan untuk mengevaluasi kondisi geomorfologi dan karakterisasi sedimen dasar laut di perairan Sebagin, Bangka Selatan. . Penelitian serupa telah dilakukan di perairan Teluk Menggris, Tanah Merah, Kecamatan Muntok Kabupaten Bangka Barat. Metodologi yang dipakai untuk mengevaluasi kondisi geomorfologi dasar laut adalah Multi Beam Echo Sounder (MBES) dan Single Beam Echo Sounder (SBES). Sedangkan untuk karakterisasi sedimen dasar laut dilakukan dengan pengukuran seismik refleksi resolusi tinggi menggunakan Sub Bottom Profiling (SBP) ${ }^{[3]}$ dan uji sampel sedimen di daerah penelitian. Hasil dari penelitian ini diharapkan dapat menjadi bahan pertimbangan bagi pihak pengambil kebijakan dalam pembangunan PLTN di Pulau Bangka.

\section{METODOLOGI}

\subsection{Lokasi Penelitian}

Secara administratrif lokasi penelitian termasuk wilayah perairan Desa Sebagin, Kecamatan Simpang Rimba, Kabupaten Bangka Selatan, Provinsi Kepulauan Bangka Belitung dan letaknya pada koordinat $105^{\circ} 06^{\prime}-105^{\circ} 11^{\prime}$ BT dan $2^{\circ} 00^{\prime}-2^{\circ} 05^{\prime}$ LS (Gambar 1).

Penelitian ini merupakan bagian dari kegiatan studi kelayakan untuk tapak Bangka Selatan khususnya aspek oseanografi yang telah dikerjakan bersama dengan PT. Surveyor Indonesia sebagai konsultan pelaksana survei.

\subsection{Kriteria Keberterimaan}

Secara khusus, analisis kondisi geomorfologi dan karakteristik sedimen dasar laut diatur dalam Perka BAPETEN No. 6 Tahun 2014 tentang Evaluasi Tapak Instalasi Nuklir untuk Aspek Meteorologi dan Hidrologi. Dalam Perka tersebut, tidak dijelaskan secara rinci mengenai kriteria keberterimaan untuk kondisi geomorfologi dan karakteristik sedimen dasar laut. Namun demikian, kondisi geomorfologi dan karakteristik sedimen dasar laut harus dianalisis sesuai Perka tersebut. 


\subsection{Metode Analisis Kondisi Geomorfologi}

Dalam menganalisis kondisi geomorfologi dasar laut daerah penelitian dilakukan survei batimetri menggunakan MBES untuk kedalaman laut lebih dari 4 meter dan SBES untuk kedalaman laut kurang dari 4 meter. Langkah pertama dalam melakukan survei batimetri adalah merancang lintasan sounding untuk dapat mencakup keseluruhan daerah penelitian. Lintasan sounding MBES mencakup garis pantai sepanjang $10 \mathrm{~km}$. Panjang tiap lintasan adalah $3 \mathrm{~km}$ dengan interval jarak antar lintasan 100 meter. Arah lintasan sounding yaitu dari Timur ke Barat. Sedangkan lintasan SBES mencakup garis pantai sepanjang 2-3 km dengan interval jarak antar lintasan $25 \mathrm{~m}$. Setelah lintasan ditetapkan, langkah berikutnya adalah melakukan pengukuran topometrik di sepanjang lintasan tersebut dengan merekam dan memplot kedalaman muka laut yang terukur ke dalam peta 1:5000. Perhitungan koreksi kedalaman harus dilakukan dengan mempertimbangkan pasang surut, kedalaman transducer dan koreksi Chart Datum Level (CDL).

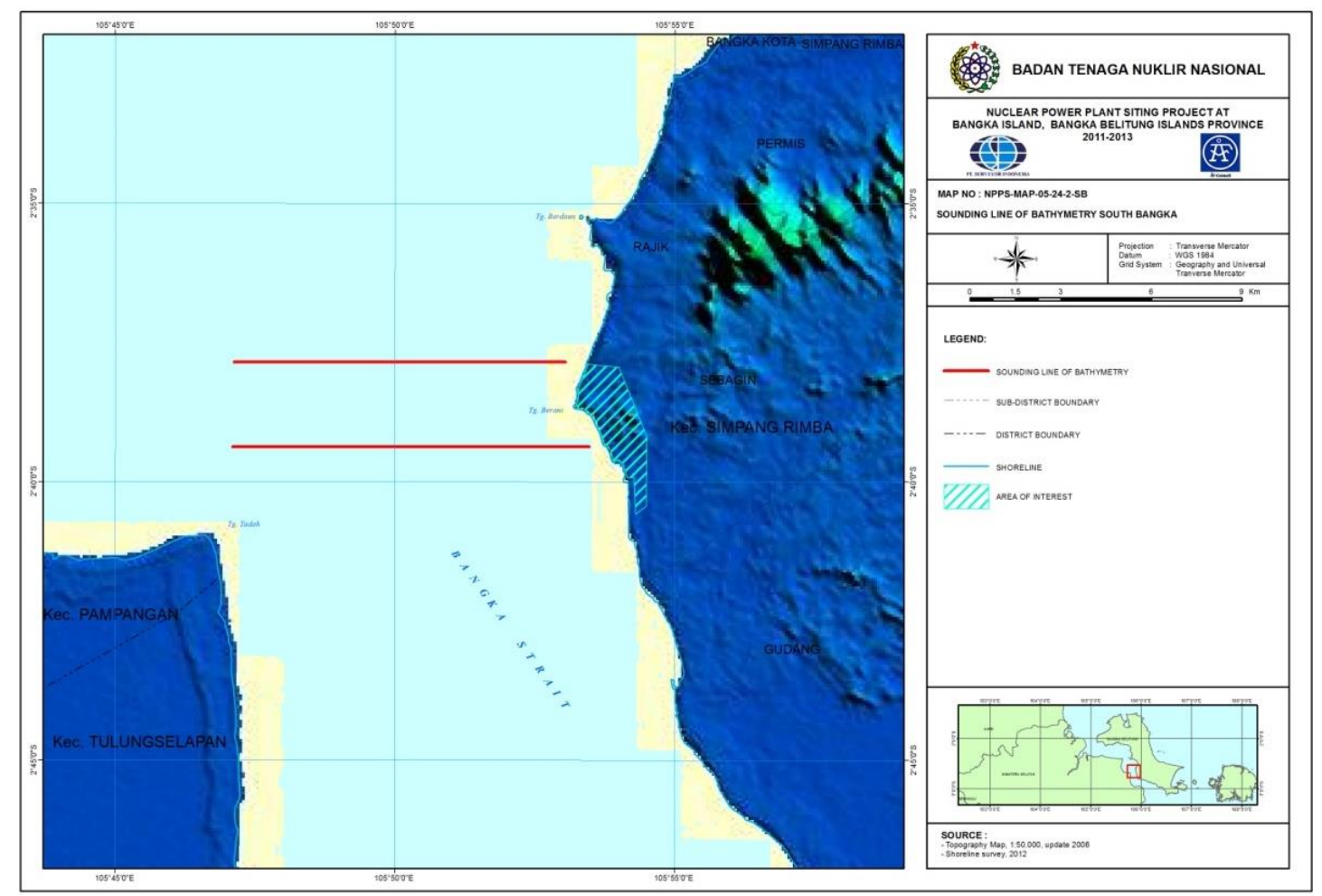

\section{Gambar 1. Lokasi Survei Identifikasi dan Karakteristik Morfologi Pesisir Tanjung Batu Berdaun di Sebagin, Bangka Selatan ${ }^{[1]}$.}

\subsection{Metode Analisis Sedimen Dasar Laut}

Untuk menganalisis pelapisan sedimen dasar laut dilakukan survei SBP yang memanfaatkan metode seismik refleksi single channel. Alat yang digunakan adalah Squid 500 Sparker dengan daya sumber 200-600 Joule. Survei ini dilakukan bersamaan dengan survei batimetri baik menggunakan MBES maupun SBES dan mencakup garis pantai sepanjang $10 \mathrm{~km}$. Lintasan SBP terdiri dari lintasan paralel dan tegak lurus garis pantai. Interval jarak antar lintasan yang tegak lurus dengan garis pantai adalah 200 meter. Sedangkan untuk lintasan yang paralel dengan garis pantai, interval jaraknya yaitu 400 meter. Survei di sekitar tapak di Bangka Selatan dan analisis data dilaksanakan pada bulan Juli sampai Agustus 2012. Jalur lintasan pelaksanaan survei dan tampilan pengambilan data lapangan ditampilkan pada Gambar 2. 
Langkah-langkah pengolahan data SBP diperlihatkan oleh Gambar 3. Selain menggunakan data SBP, karakterisasi sedimen dasar laut juga dilakukan dengan uji sampel sedimen yang diambil di 10 titik sampling (lihat Gambar 4). Delapan sampel diambil menggunakan gravity corer dan 2 sampel lainnya diambil menggunakan Grab sampler. Analisis uji laboratorium terhadap sampel sedimen tersebut memberikan basis dalam interpretasi stratigrafi sedimen dasar laut.

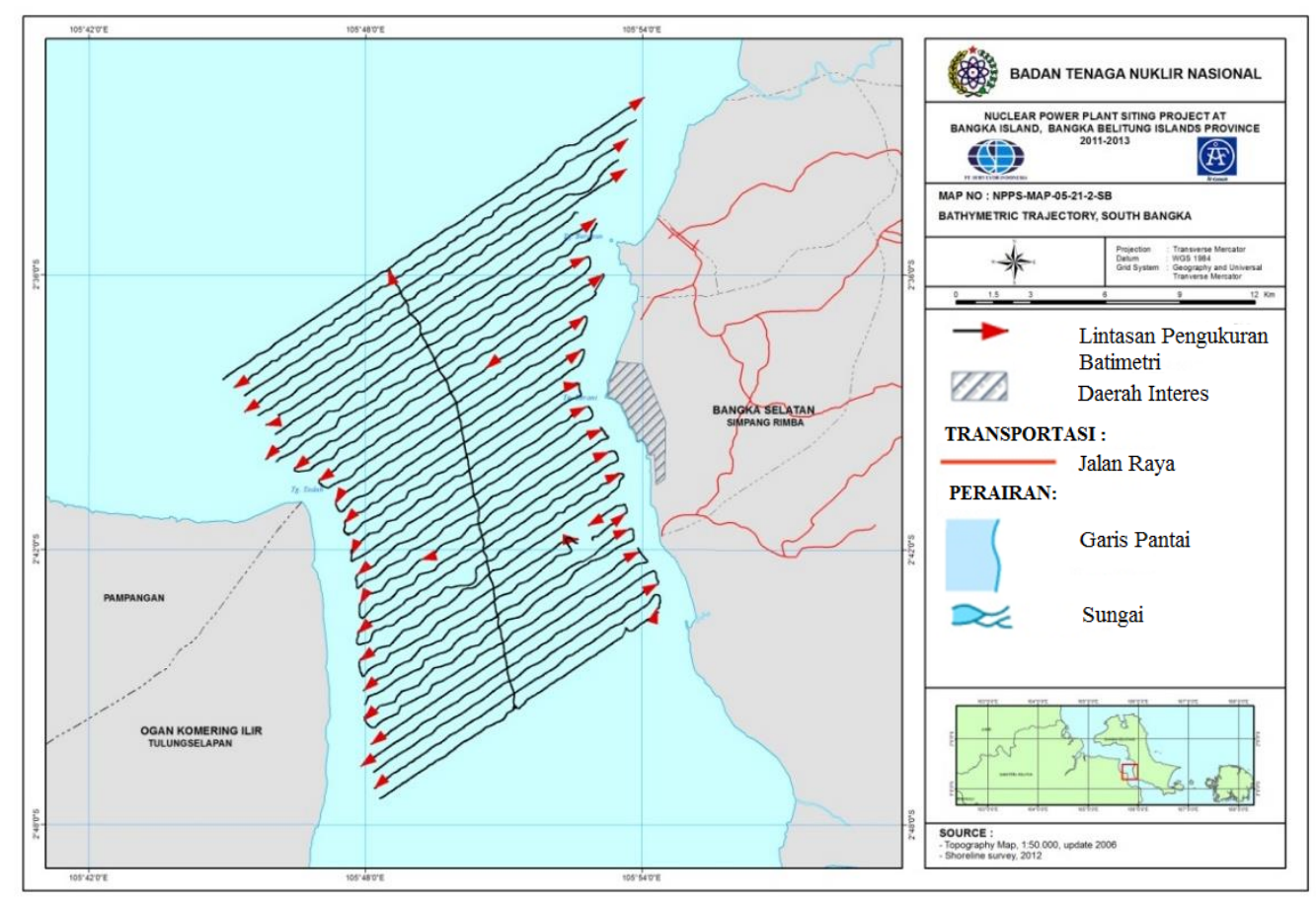

Gambar 2. Jalur Lintasan Seismik Bangka Selatan ${ }^{[1]}$.

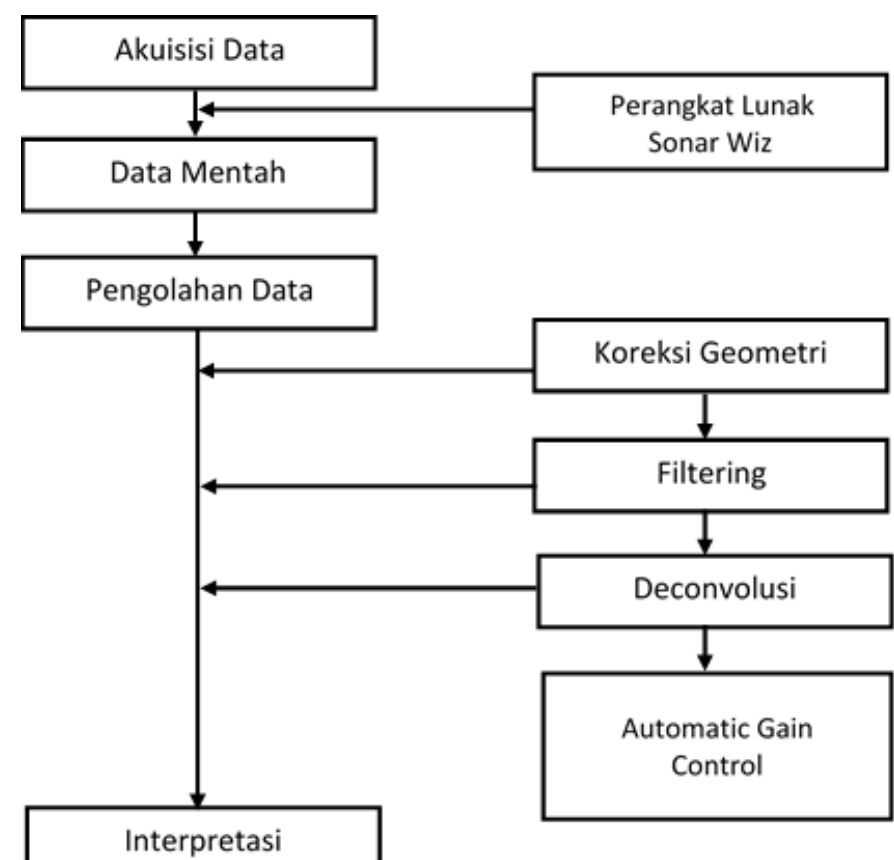

Gambar 3. Pengolahan Data SBP. 


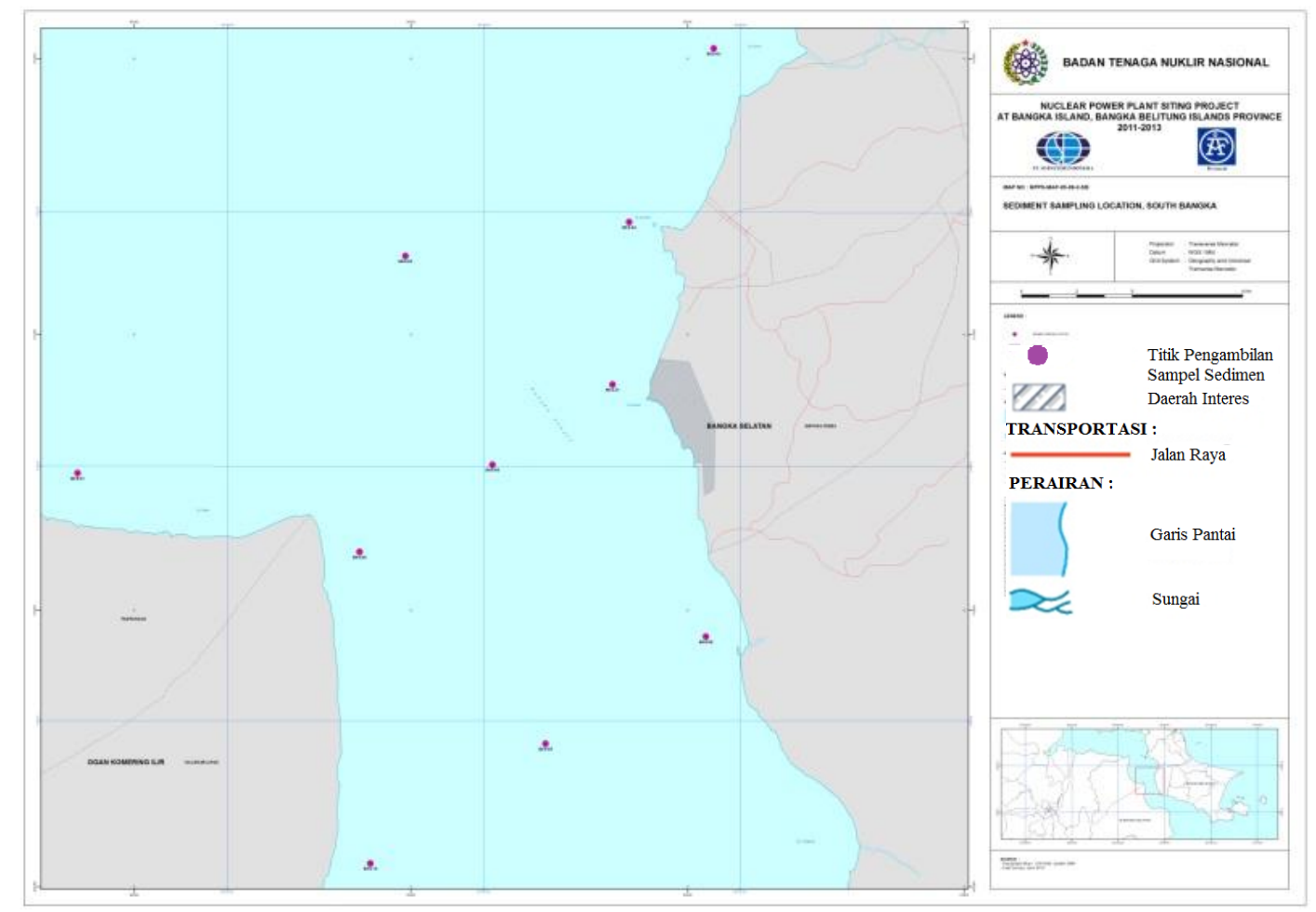

Gambar 4 Titik Pengambilan Sampel Sedimen Dasar Laut ${ }^{[1]}$.

\section{HASIL DAN PEMBAHASAN}

\subsection{Geologi Lepas Pantai}

Geologi dasar laut daerah Bangka - Belitung termasuk daerah Paparan Sunda. Kondisi ini secara regional sangat dipengaruhi perubahan muka air laut pada zaman Kenozoikum akhir. Geologi dasar laut Jawa dan Paparan Sunda dipengaruhi oleh perubahan muka laut/genang laut pada zaman Pleistosen. Data menunjukkan adanya indikasi kehadiran sungai purba di bawah dasar laut yang ditafsirkan berdasarkan data batimetri dan seismik pantul dangkal. Data endapan dasar laut mengklarifikasikan berupa lumpur terrigenus berasal dari sedimen yang kaya akan kuarsa dengan sejumlah kecil abu volkanik[4].

Daerah penelitian, ditinjau dari aspek geologi lepas pantai merupakan bagian dari perairan Paparan Sunda yang termasuk ke dalam perairan laut dangkal $(<85 \mathrm{~m})$. Data endapan dasar laut yang telah diteliti menunjukkan bahwa sedimen yang diperoleh menunjukkan endapan dasar laut di paparan Sunda yang terdiri dari beberapa jenis endapan dan sedimen kuarter.

Data seismik refleksi sepanjang $920 \mathrm{~km}$ (19 lintasan) diperoleh dalam bentuk data rekaman analog menerus. Berdasarkan hasil pengolahan data, pemerian dan penafsiran terhadap seluruh rekaman seismik yang diperoleh, didapat gambaran secara umum keadaan geologi bawah permukaan daerah telitian. Interpretasi rekaman seismik difokuskan pada profil yang menunjukkan pola konfigurasi reflektor yang khas.

Berdasarkan peta batimetri hasil pemetaan di perairan Sebagin Bangka Selatan, geomorfologi dasar laut daerah regional mengikuti aliran perairan Selat Bangka dengan arah Utara - Selatan dan ditengah-tengah selat terdapat cekungan berbentuk bulat yang memanjang dari arah barat laut - tenggara, sebagaimana ditunjukkan pada Gambar 5. 
Secara umum, pola kontur batimetri terlihat sejajar dengan daerah garis pantai Selat Bangka dan pesisir Sumatera. Kondisi batimetri dalam posisi tiga dimensi ditunjukkan pada Gambar 6.

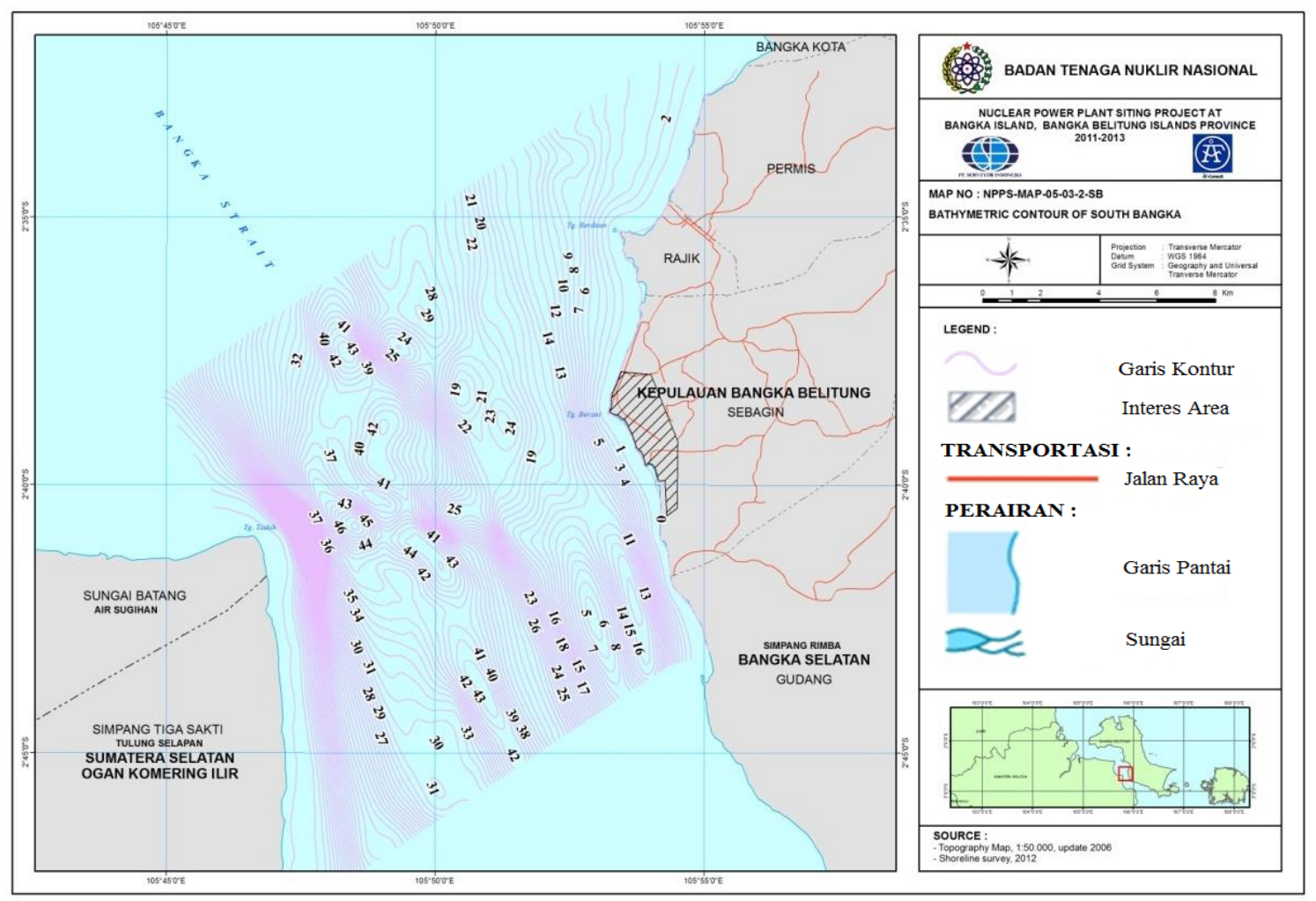

Gambar 5. Peta Kontur Batimetri di Bangka Selatan ${ }^{[1,8]}$.
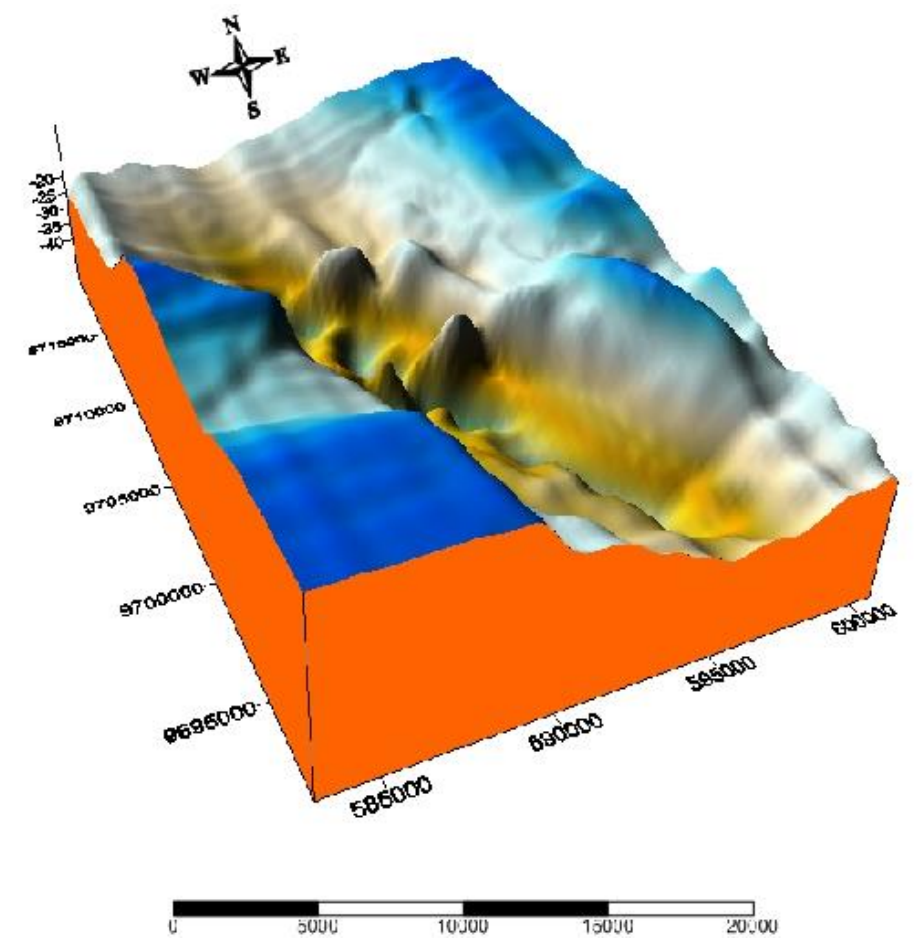

Gambar 6. Kondisi Batimetri dalam 3 Dimensi Perairan Bangka Selatan ${ }^{[1]}$. 


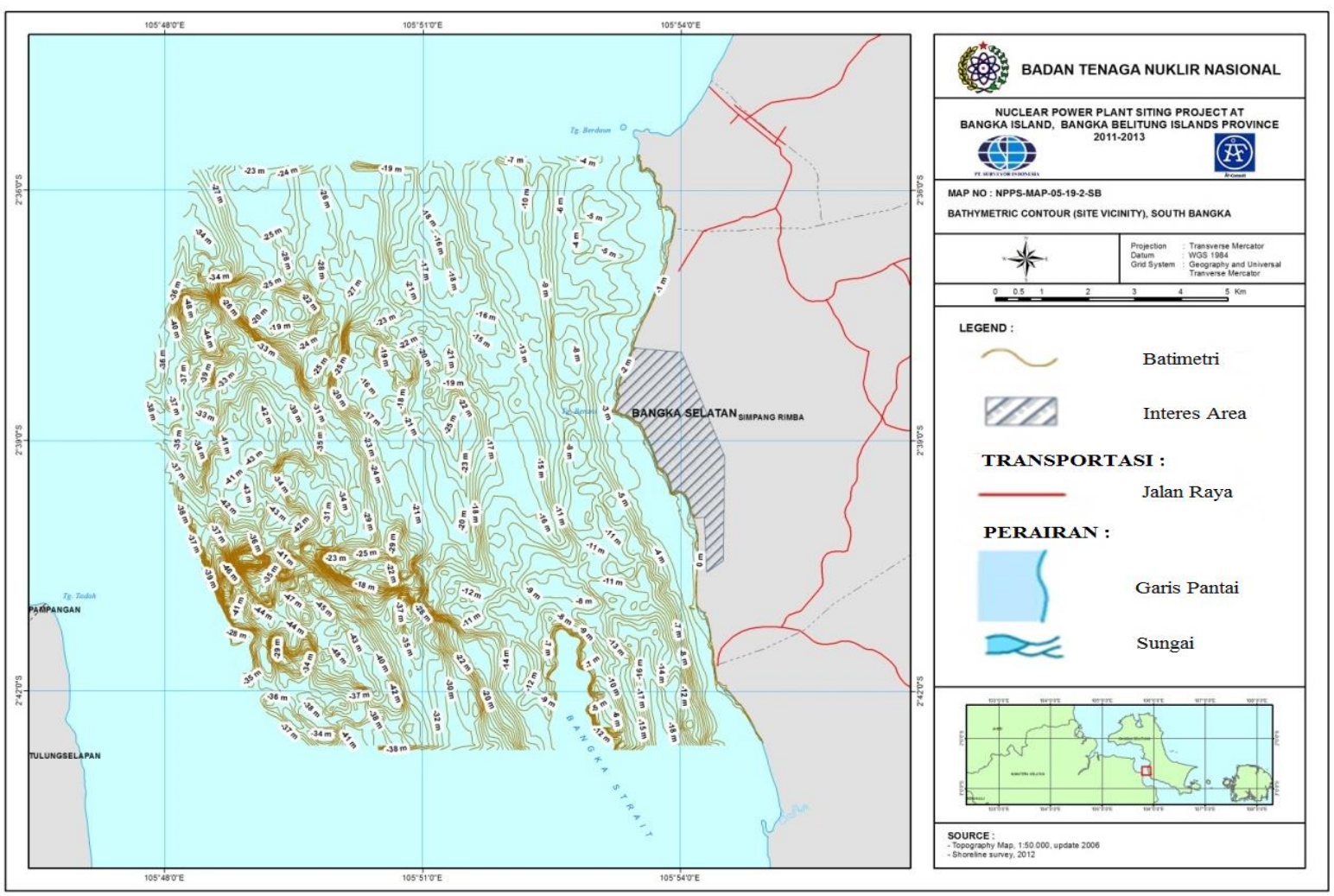

\section{Gambar 7. Kondisi Kontur Batimetri di Site Vicinity ${ }^{[1,8]}$.}

Hasil survei batimetri di perairan Tanjung Berani, Sebagin, Selat Bangka pada umumnya menunjukkan bahwa pola distribusi kontur batimetri adalah memanjang sepanjang garis selat dengan kedalaman maksimum $59 \mathrm{~m}$ lepas pantai Sebagin, Bangka Selatan dan $49 \mathrm{~m}$ lepas pantai Bangka Selatan. Posisi batimetri terdalam adalah di daerah Selat Bangka yang berdekatan dengan pulau Sumatera (Gambar 7).

Morfologi dasar laut berikut Selat Bangka berarah Utara - Selatan dan pusatnya lebih dalam karena terdiri dari lembah dan pegunungan dengan bentuk oval panjang berarah Barat Laut - Tenggara. Pola kontur batimetri secara paralel terhadap garis pantai Selat Bangka dan Pulau Sumatera. Batimetri daerah survei adalah 1-59 meter dengan interval kontur $1 \mathrm{~m}$. Daerah terdalam terlihat dari garis kontur $59 \mathrm{~m}$ yang berada di titik tengah kontur yang berbentuk bulat panjang dan berada di sepanjang garis tegak arah arus ${ }^{[6]}$.

Perairan sekitar Tanjung Batu Berdaun-Tanjung Berani di desa Sebagin menunjukkan pola kontur yang kurang teratur. Hal ini diduga karena banyaknya aktifitas penambangan timah dengan kapal isap yang cenderung merusak dan menyebabkan profil dasar laut tidak beraturan dan banyak lembah. Tingkat kecuraman mencapai sekitar 1,25\% di pantai Bangka Selatan dan miring ke arah pantai Sumatera dengan rata-rata kemiringan 0,25\%. Arus yang besar terdapat di Tanjung Batu Berani. Pola ini sangat berbeda dari hasil batimetri lepas pantai Sumatera yang teksturnya miring ke arah garis pantai.

Hasil interpretasi seismik refleksi juga telah memetakan kontur ketebalan sedimen (isopach) Holocene seperti diperlihatkan Gambar 8. 


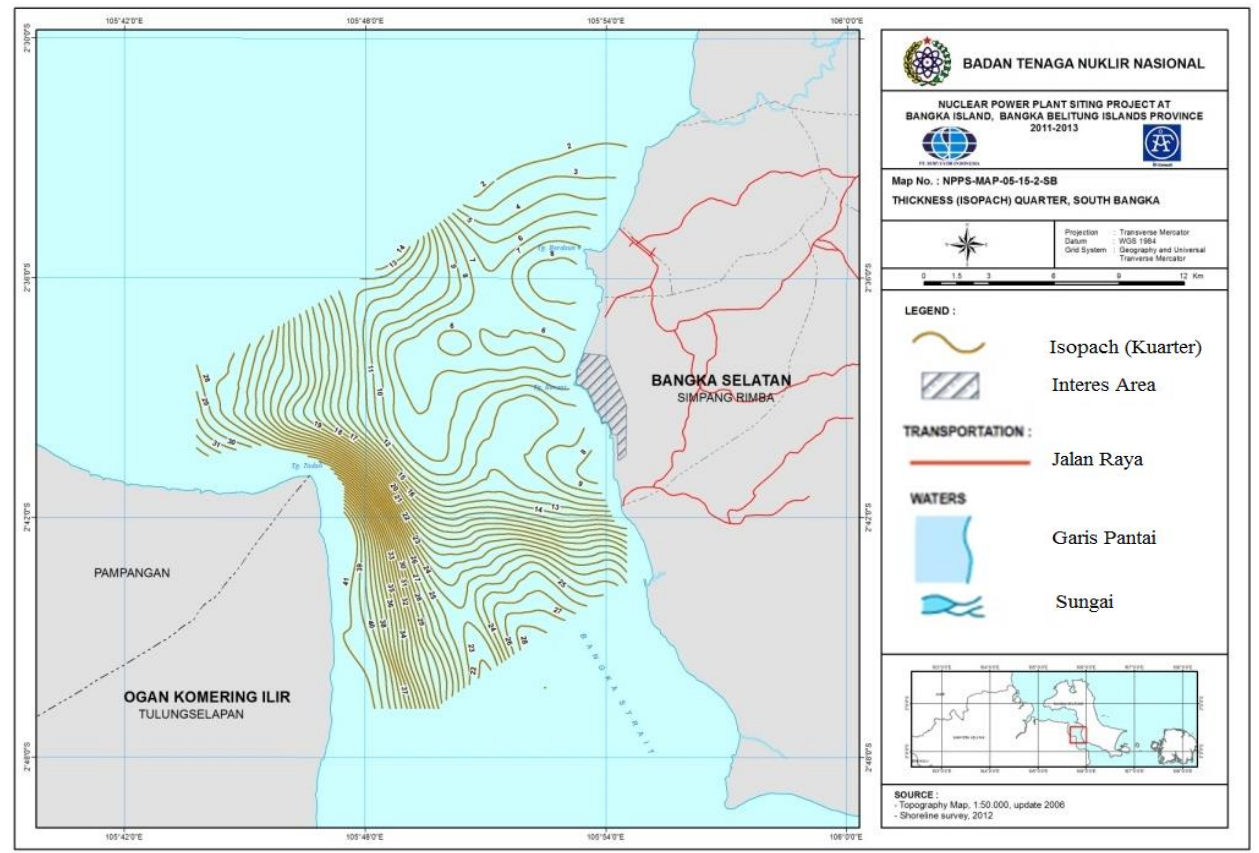

Gambar 8. Kontur dari Ketebalan Sedimen (isopach) Holocen di Bangka Selatan ${ }^{[1]}$.

Penyelidikan yang telah dilakukan oleh P3GL (Pusat Penelitian dan Pengembangan Geologi Kelautan) berkaitan dengan Penyelidikan Seismik dan Percontohan Gaya berat di perairan Sebagin, Bangka Selatan pada 1985 menunjukkan bahwa kedalaman dasar laut maksimum sekitar 37,5 m yang terletak di bagian tengah daerah penyelidikan, di bagian selatan terbentuk punggungan dengan arah Timur - Barat dengan kedalaman minimum 7,5 m ke arah utara membentuk alur (channel) besar dengan kedalaman $15 \mathrm{~m}-38 \mathrm{~m}$ searah garis pantai ${ }^{[5]}$. Hasil rekaman seismik memperlihatkan geologi bawah permukaan dasar laut dapat dibagi menjadi 4 sekuen. Berdasarkan analisis penampang seismik diperoleh informasi bahwa basement di daerah penelitian merupakan batuan metasedimen atau batuan beku. Lapisan di atasnya adalah endapan aluvial tua dan endapan (Formasi) Ranggam yang terbentuk pada pertengahan sampai akhir Tersier. Di atas Formasi Ranggam terdapat Formasi Ladang dan secara tidak selaras menutupi Formasi Ranggam. Endapan aluvial Resen (Ranggam) kaya akan kandungan kasiterit. Pola struktur yang berkembang adalah sesar mendatar berarah timur laut - barat daya memotong sedimen Tersier di daerah ini. Hasil analisa kimia sedimen dasar laut diketahui bahwa daerah penyelidikan kaya akan mineral-mineral seperti kasiterit, turmalin, rutil, ilmenit, monasit dan apatit berasal dari batuan granit ${ }^{[5]}$.

\subsection{Seismik Refleksi}

Hasil survei menunjukkan bahwa survei seismik refleksi di daerah lepas pantai di daerah penelitian tidak menunjukkan struktur sesar. Selain itu diperoleh informasi zona sedimen dangkal yang didefinisikan antara dasar laut dan sekitar 45 meter di bawah dasar laut[5]. Berdasarkan penampilan catatan seismik analog dan adanya batas-batas yang berbeda, sedimen dangkal telah dibagi menjadi empat (4) unit stratigrafi, disebut A sampai C[1,9].

\section{UNIT A}

Unit A merepresentasikan sedimen yang terdiri atas lempung (clay) lembut sampai dengan sangat lembut yang ditumpangsusun (overlay) dengan lapisan pasir. Dasar unit digambarkan oleh ketidakteraturan di sepanjang permukaan reflektor yang kuat dan dengan koherensi yang buruk (dinyatakan dengan R1). Kemiringan lapisan direkam di tempat. Di 
beberapa bagian, dari unit ini tampak baik, sedangkan di bagian luar terjadi erosi yang menyebabkan ketidakteraturan dasar laut. Pada unit ini tidak terindikasi adanya singkapan (outcrop) dasar laut. Ketebalan unit bervariasi dari nol hingga $15.6 \mathrm{~m}$ dari permukaan dasar laut. UNIT B

Unit ini ditandai dengan undulasi tidak teratur, koherensi kecil, dan reflektor dari rendah sampai sedang. Hal ini diinterpretasikan sebagai lempung pasiran. Unit B ditandai dengan rona yang berbeda dinyatakan sebagai $\mathrm{R} 2$, dijumpai antara 5 sampai $25 \mathrm{~m}$ di dasar laut. UNIT C

Unit ini menunjukkan undulasi reflektor tidak teratur dari rendah sampai sedang. Hal ini diinterpretasikan sebagai lempung keras/ padat dengan sisipan pasir, mempunyai ketebalan yang bervariasi dan terletak lebih dari 25 meter di dasar laut.

Diagram berikut merupakan beberapa contoh rekaman seismik dengan batasan analisis berbeda (Gambar 9-12).

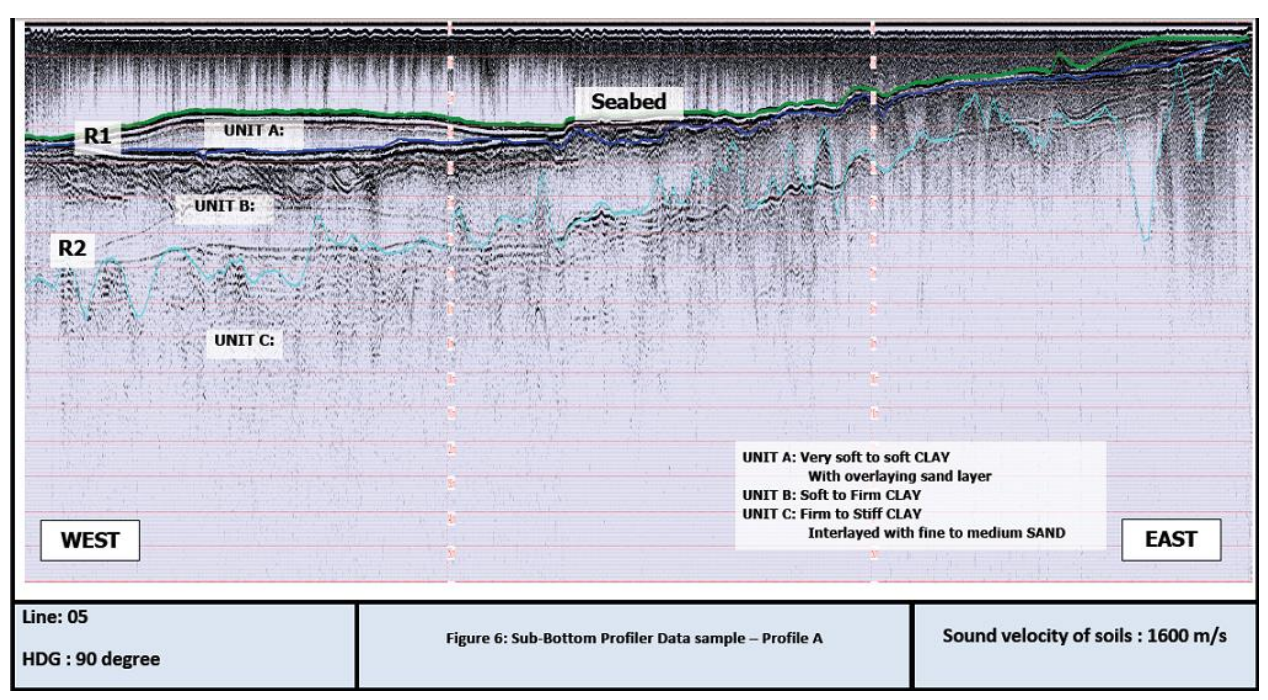

Gambar 9. Data Sampel Sub-Bottom profiling- profile Line- $05^{[1]}$.

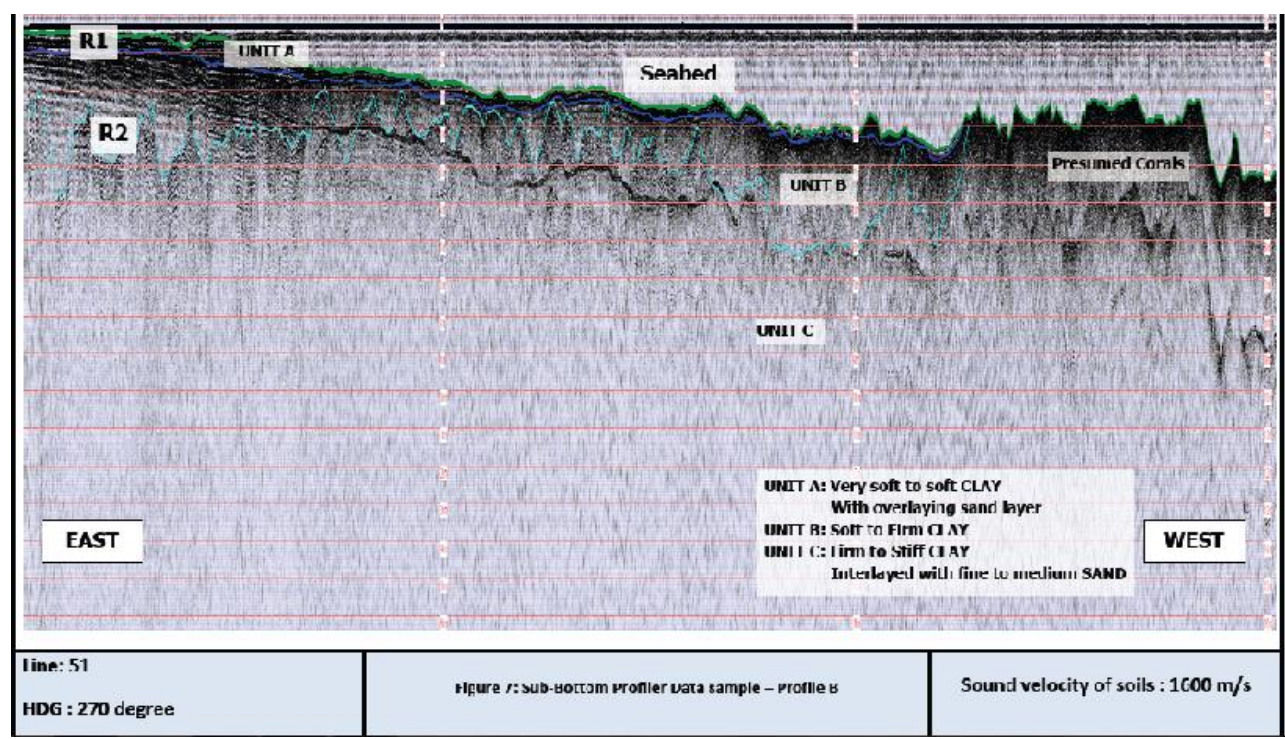

Gambar 10. Data Sampel Sub-Bottom Profiling - profile Line-51 ${ }^{[1]}$. 


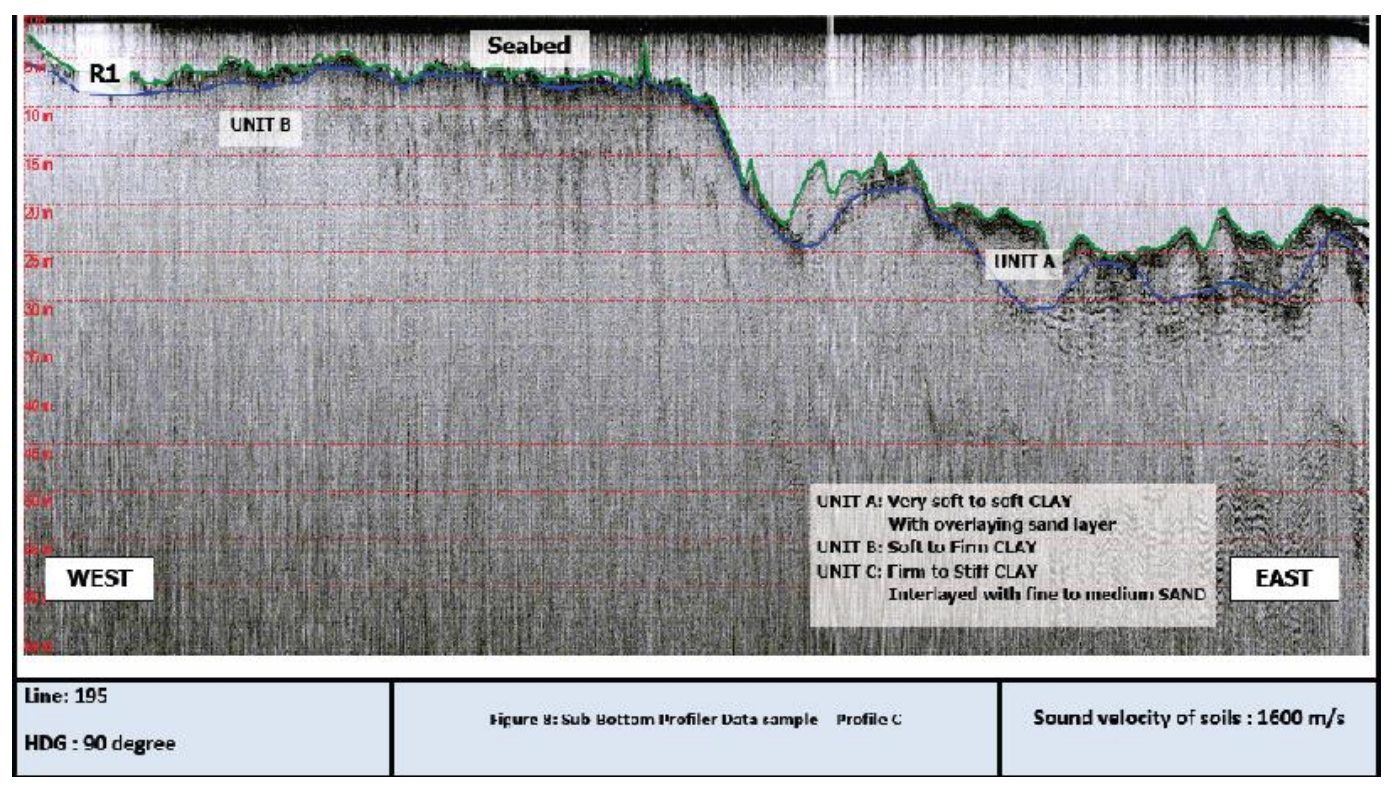

Gambar 11. Data Sampel Sub-Bottom Profiling-profile Line 195 ${ }^{[1]}$.

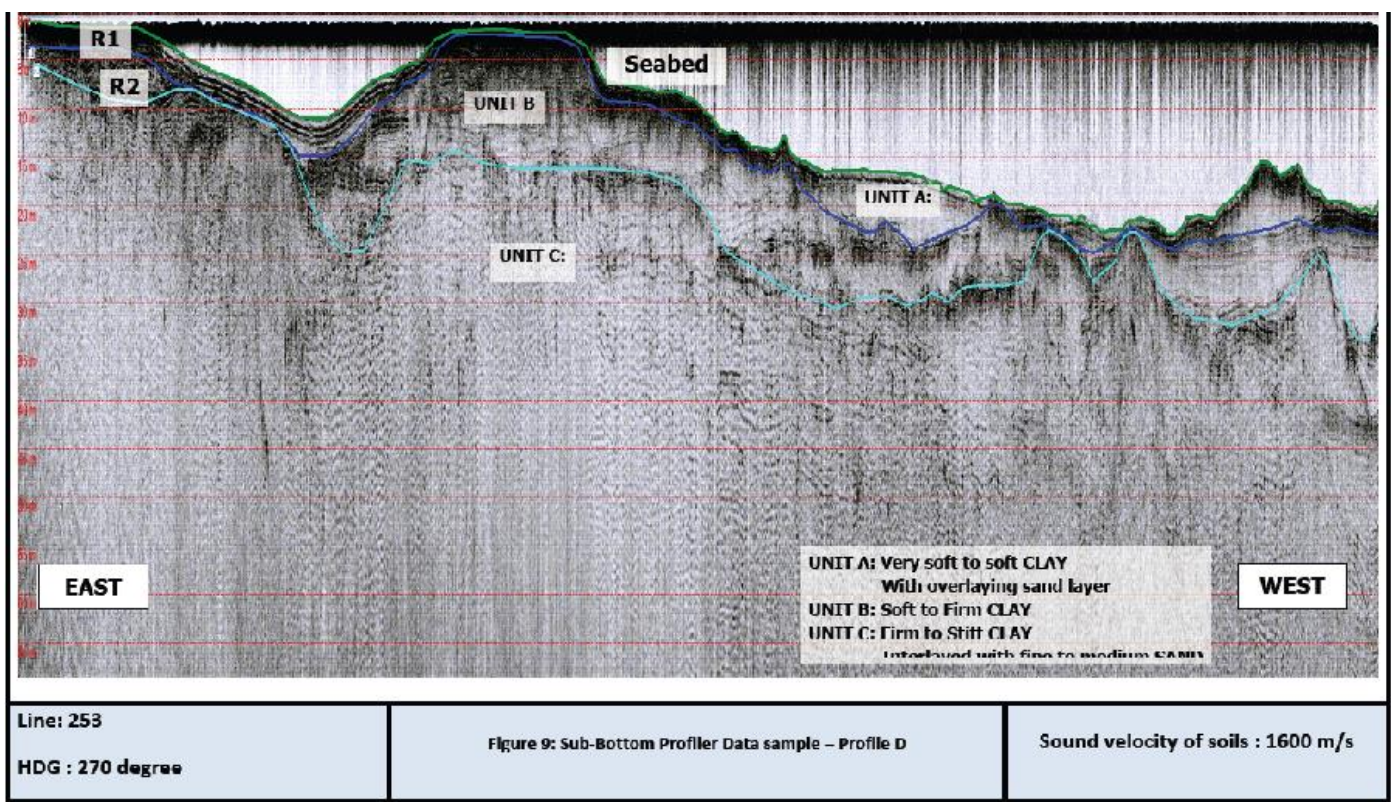

Gambar 12. Data Sampel Sub-Bottom Profiling - profile Line-253 ${ }^{[1]}$.

Dibandingkan profil sedimen dasar laut di perairan Teluk Mengris, Muntok, Bangka Barat yang telah dievaluasi[1,9], profil sedimen dasar laut di perairan daerah Sebagin, Bangka Selatan lebih teratur kondisi topografi dasar lautnya. Hal ini diperkirakan karena penambangan timah di dasar laut untuk wilayah perairan di Bangka Barat lebih banyak aktifitasnya, baik oleh penambangan legal maupun yang ilegal.

\subsection{Pola Sebaran Sedimen Perairan}

Gambar 13 menunjukkan kondisi pola sebaran sedimen di daerah perairan Bangka Selatan, dimana distribusi lumpur (silt) telah mendominasi daerah survei yaitu sekitar $85 \%$ 
dengan pola penyebaran merata hampir di seluruh Selat Bangka, sejajar dengan garis pantai pulau Sumatera dan pulau Bangka. Adapun komposisi lumpur yang telah dianalisis menunjukkan persentase pasir antara $0-6,1 \%, 92,3-98,1 \%$ terdiri atas lumpur, dan 1,0 - 1,9\% terdiri atas tanah liat.

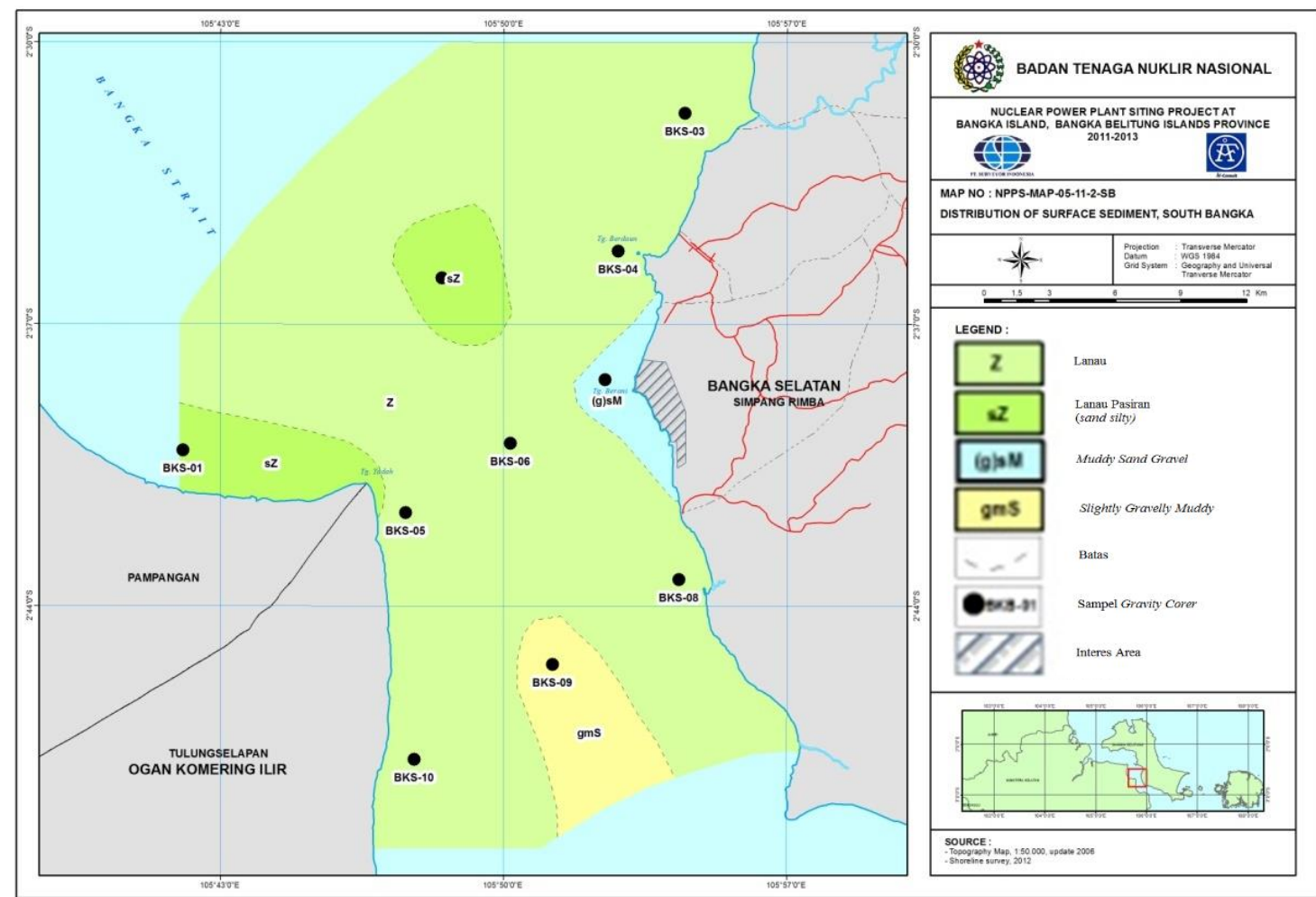

Gambar 13. Pola Distribusi Sedimen Air Permukaan di Perairan Bangka Selatan ${ }^{[1]}$.

Kondisi geomorfologi dan karakteristik sedimen dasar laut tidak menjadi salah satu kriteria keberterimaan dalam penentuan kelayakan tapak PLTN. Namun demikian, kedua item ini menjadi signifikan sebagai parameter desain dalam mempertimbangkan penentuan lokasi water intake bagi sistem pendingin PLTN (dalam hal ini reaktor berjenis PWR). Berdasarkan hasil penelitian, lumpur yang mendominasi perairan di daerah penelitian, akan mempengaruhi sistem water intake, sehingga perlu solusi rekayasa untuk menangani hal tersebut. Misalnya dengan menempatkan posisi water intake pada daerah yang mempunyai kedalaman lebih dari $25 \mathrm{~m}$ untuk menghindari pengaruh lumpur (sedimen lempung). Terkait aspek kegempaan, tidak adanya indikasi sesar di laut pada lapisan Kuarter menunjukkan bahwa daerah ini dapat dikatakan stabil atau aman.

\section{KESIMPULAN}

Dari hasil penelitian dapat disimpulkan, bahwa daerah penelitian di perairan Tanjung Batu Berdaun-Tanjung Berani sebagai tapak PLTN merupakan perairan dangkal dengan kedalaman 1- 59 m. Posisi batimetri terdalam adalah di daerah Selat Bangka yang berdekatan dengan pulau Sumatera. Profil geomorfologi dasar laut daerah penelitian cenderung tidak beraturan dan berdasarkan interpretasi seismik tidak ditemukan adanya patahan. Hasil analisis sedimen dasar laut menunjukkan bahwa, distribusi lumpur mendominasi daerah perairan calon tapak PLTN. Informasi batimetri dan karakteristik sedimen dasar laut hasil penelitian 
dapat dijadikan sebagai parameter desain dalam mempertimbangkan penentuan lokasi water intake bagi sistem pendingin PLTN (dalam hal ini reaktor berjenis PWR).

\section{DAFTAR PUSTAKA}

[1]. PT. SURVEYOR INDONESIA-AF CONSULTANT, “Oceanographical Investigations Database and Dispersion Characteristics-South Bangka", Final Topical Report-Year 2, NPP Siting Project, 2013.

[2]. SUSIATI, H., dkk., "Studi Rona Awal Lingkungan pada Tahap Pra-Survei Tapak di Dua Daerah Interes Untuk PLTN di Pulau Bangka", Prosiding Seminar Teknologi Energi Nuklir 2011, ISSN: 2355-7524, Pusat Pengembangan Energi Nuklir-BATAN, Jakarta, 2011.

[3]. HAQQU, R., "Deteksi dan Karakterisasi Akustik Sedimen Dasar Laut Dengan Teknologi Seismik Dangkal di Peraiaran Rambat, Bangka Belitung", Jurnal Ilmu dan Teknologi Kelautan Tropis, 5, Hal. 441-452, 2013.

[4]. KURNIAWAN, D. S., NGADENIN, "Geologi Daerah Muntok dan Potensi Granit Menumbing Sebagai Sumber Uranium (U) dan Thorium (Th)", Eksplorium, 34, Hal. 137149, Desember 2013.

[5]. Mangga, S.A. dan Djamal, B., "Peta Geologi Lembar Bangka Utara dan Bangka Selatan", Pusat Penelitian Pengembangan Geologi, Bandung, 1994.

[6]. P3GL, "Penyelidikan Geologi dan Geofisika Kelautan Perairan Bangka Belitung, Lembar 1215", Pusat Penelitian Pengembangan Geologi, Bandung, 2002.

[7]. HENDRO, D.B., LILIS, L., SLAMET, DERY, R., “Direktori Laporan Penyelidikan / Penelitian Pusat Penelitian dan Pengembangan Geologi Kelautan Seri I", Pusat Penelitian dan Pengembangan Geologi Kelautan", 2012.

[8]. PT. SURVEYOR INDONESIA DAN AF CONSULTANT, "Informasi Data Tapak Bangka Selatan untuk Pembangkit Listrik Tenaga Nuklir", Proyek Tapak Pembangkit Listrik Tenaga Nuklir di pulau Bangka, Provinsi Bangka Belitung, 2013.

[9]. SUSIATI. dan YULIASTUTI, "Karakteristik Sedimen Dasar Laut untuk Evaluasi Lokasi Tapak PLTN di Bangka Barat", Prosiding Seminar Nasional Geologi Nuklir dan Sumber Daya Tambang Tahun 2014, Pusat Teknologi Bahan Galian Nuklir, 2014.

[10]. HASANUDIN, M., "Morfologi Dasar Laut dan Ketebalan Sedimen Permukaan Perairan Kalimantan Selatan", Jurnal Oseanologi, LIPI, Jakarta, 2012. 